\title{
Interaction effects of nitric oxide and salicylic acid in alleviating salt stress of Gossypium hirsutum L.
}

\author{
Y.J. Dong, ${ }^{1,2,3}$, Z.L. Wang', J.W. Zhang', S. Liu' ${ }^{1}$, Z.L. He ${ }^{3}$, M.R. $\mathrm{He}^{2 *}$ \\ ${ }^{1}$ College of Resources and Environment, Shandong Agricultural University, Tai'an 271018, Shandong P.R.China. \\ ${ }^{2}$ College of Agronomic Sciences, Shandong Agricultural University, Tai'an 271018, Shandong Province, \\ P.R.China. *Corresponding author: mrhe@sdau.edu.cn. ${ }^{3}$ University of Florida, Institute of Food and Agricultural
} Sciences, Indian River Research and Education Center, 2199 S. Rock Road, Fort Pierce,FL 34945, United States.

\begin{abstract}
The effects of sodium nitroprusside (SNP, a nitric oxide donor), salicylic acid (SA), and their combination on some physiological parameters of cotton (Gossypium hirsutum L.) seedlings grown under saline conditions were studied. $100 \mathrm{mM} \mathrm{NaCl}$ resulted in a decrease in photosynthetic attributes and chlorophyll content, and induced an increase in the level of electrolyte leakage, malondialdehyde (MDA) content, $\mathrm{O}_{2} \cdot-$ generation rate, $\mathrm{H}_{2} \mathrm{O}_{2}$ and proline contents. $0.1 \mathrm{mM} \mathrm{SNP}$ decreased $\mathrm{Na}^{+}$and $\mathrm{Cl}^{-}$accumulation as well as the lipid peroxidation level and $\mathrm{O}_{2}$-accumulation in leaves, which contributed to alleviate oxidative stress in cotton leaves. $0.1 \mathrm{mM} \mathrm{SA}$ alleviated the oxidative stress by increasing $\mathrm{K}^{+}$and $\mathrm{Mg}^{2+}$ absorption and osmotic regulators accumulation, and decreasing the $\mathrm{H}_{2} \mathrm{O}_{2}$ content. However, the protective action of NO and SA (especially $0.05 \mathrm{mM}$ SNP and 0.05 mM SA) against salt-induced oxidative damage was more efficient than the separate effects of SA and SNP.We observed that the accumulation of osmotic regulators was apparently accelerated by $0.05 \mathrm{mM} \mathrm{SNP}$ and $0.05 \mathrm{mM}$ SA. As well, it was observed that they had synergistic effects in antioxidant system and ion absorption. Thus, the combination of SNP and SA can be a new indicator of a protective mechanism to lower lipid peroxidation, improve ion absorption, activate the metabolic of osmotic-regulated substances and facilitate the membrane transport to detoxify reactive oxygen species (ROS).
\end{abstract}

Keywords: Antioxidant enzymes, cotton, nitric oxide, $\mathrm{NaCl}$, oxidative stress, salicylic acid

Abbreviations: CAT-Catalase; DW-Dry weight; FW-Fresh weight; $\mathrm{H}_{2} \mathrm{O}_{2}$-Hydrogen peroxide; MDA-Malondialdehyde; $\mathrm{NaCl}$-Sodium chloride; $\mathrm{NO}-\mathrm{Nitric} \mathrm{oxideO}_{2}{ }^{-}$-Superoxide anion; POD-Peroxidases; ROS-Reactive oxygen species; SNP-Sodium nitroprusside; SA -Salicylic acid; SOD-Superoxide dismutase 


\section{Introduction}

Salinity is one of the important factors affecting growth and metabolic responses of crops throughout the world (Deinlein et al., 2014). Salt-affected plants deteriorate as a result of ROS production such as the superoxide radical $\left(\mathrm{O}_{2}^{-}\right)$, hydrogen peroxide $\left(\mathrm{H}_{2} \mathrm{O}_{2}\right)$, hydroxyl radical $(\bullet \mathrm{OH})$ and singlet oxygen $\left({ }^{1} \mathrm{O}_{2}\right)$ that can damage mitochondria and chloroplasts by disrupting cellular structures (Tariq et al., 2011). Excess of ROS triggers phytotoxic reactions such as lipid peroxidation, enzymes inactivation and protein degradation. These changes lead to osmotic and ion-specific effects as well as to imbalances in plant nutrition, which may range from deficiencies in several nutrients (Qadir et al., 2006). To mitigate and repair the damage, plant cells detoxify ROS by the synchronous action of various antioxidants constituted of non-enzymatic and enzymatic components. Superoxide dismutase (SOD), peroxidase (POX), catalase (CAT), ascorbate peroxidase (APX) and glutathione reductase (GR) are the enzymatic antioxidants, while water soluble components (sugars and proteins) and the lipid-soluble components (carotenoids and $\alpha$-tocopherol) are the non- enzymatic antioxidants (Sheetal et al., 2012). Hence, the alleviation of the oxidative damage and increased resistance to salinity and other environmental stresses are often correlated with an efficient antioxidative system and an accumulation of water-soluble component.

Nitric oxide (NO) is a small, highly diffusible gas and an ubiquitous bioactive molecule. Its chemical properties make NO a versatile signal molecule that functions through the interactions with cellular targets via either redox or additive chemistry (Lamattina et al., 2003). Undoubtedly, there are many studies show that NO itself is the plant signaling molecule, and today it is known to play a crucial role in regulating many key physiological processes in different plants, such as in rice, cucumber, mung bean and so on (Panda et al., 2011). Various mechanisms contribute to NO-induced increase of salt tolerance. First, NO might be involved in increasing the antioxidant content and antioxidant enzyme activity to scavenge ROS. Second, NO might increase risk element accumulation in root cell walls and decrease the risk element accumulation in the soluble cell fraction to maintain the cellular redox homeostasis and regulation of the leaves (Panda et al., 2011; Manai et al. 2014). Finally, NO could function as a signaling molecule in the cascade of events leading to changes in gene expression under risk element stress (Xiong et al., 2009). However, an access amounts of $\mathrm{NO}$ may interact with $\mathrm{O}_{2}{ }^{--}$to form peroxynitrite $\left(\mathrm{ONOO}^{-}\right)$, which has been reported to damage lipids, proteins and nucleic acids. Nevertheless, $\mathrm{O}_{2}{ }^{-}$and $\mathrm{H}_{2} \mathrm{O}_{2}$ are more toxic than $\mathrm{NO}$ and $\mathrm{ONOO}^{-}$. This type of dual roles of $\mathrm{NO}$ as a potent oxidant or effective antioxidant generally depends on the status of the environments (Panda et al., 2011) and also contents.

Salicylic acid (SA) is another signaling molecule or chemical messenger and its role in the defense mechanism is well-established under stress conditions (Gunes et al., 2005). A large number of studies have reported the effects of exogenous SA on alleviating environment stress, including salt (Misra et al., 2009), heavy metal (Sanjib et al., 2007), water and chilling, by the stimulation of growth. SA has been reported to ameliorate the adverse effects of salinity by improving the functioning of ion uptake and transport, membrane permeability, and antioxidative enzymes (Gunes et al., 2005). Furthermore, SA is also considered to be a signaling molecule that plays a key role in growth, development, and defense responses in plants under stress conditions. Although a few authors have reported the effects of exogenous NO and SA alleviating salt toxicity in different plants by various 
mechanisms, information is still scant regarding the influences of NO and SA on salt tolerance improvement in cotton seedlings.

Cotton (Gossypium hirsutum L.) has been considered as an important crop for fibre production in several countries. This species can grow well in saline areas, indicating tolerance to salt stresses (Silva et al., 2010; Wang et al. 2014); however, it is sensitive to salt in the seedling stage (Liu et al., 2013). Therefore in the present study, we suppose that NO and SA may ameliorate toxic effects of excess $\mathrm{Na}$ on cotton. Furthermore, it is also of a great interest to know whether exogenous NO and SA could act as a regulator of antioxidant intervention strategy in preventing leaf oxidative stress in response to $\mathrm{NaCl}$ stress to improve the oxidation resistance capacity, and to get a better understanding of how plants adjust to an adverse environment.

\section{Materials and Methods}

\subsection{Plant materials and experimental design}

Before sowing, healthy seeds of cotton (Gossypium hirsutum L.) were surface-sterilized with $1 \%$ sodium hypochlorite for $10 \mathrm{~min}$, and then vigorously rinsed with distilled water. The seeds were sown in plastic pots filled with matrix. The pots were arranged in a growth chamber $\left(28 / 20{ }^{\circ} \mathrm{C}\right.$; day/night, light intensity $150 \mu \mathrm{mol} / \mathrm{m}^{2} / \mathrm{s}$, 14-hour photoperiod, $60 \%$ relative humidity) to cultivate. After germination, 7-day-old seedlings were cultivated in a hydroponics system in the growth chamber. $100 \mathrm{mM} \mathrm{NaCl}$ (Sigma, USA) without or with SNP (0.05 or $0.1 \mathrm{mM}$, Sigma, USA) or SA ( 0.05 or $0.1 \mathrm{mM}$, Sigma, USA) were added to Hoagland solution during the third week of seedling growth (We determine the concentrations used for SNP, SA and $\mathrm{NaCl}$ in this study according to the experiment of ourselves (Liu et al., 2013) and the experiment of other person (Dong et al.,2014).
SNP was used as a donor of NO. The Hoagland solution was daily renewed.

\subsection{Chemical treatment}

$\mathrm{NaCl}$, SNP and SA treatments were as follows: (1) control, CK; (2) $100 \mathrm{mM} \mathrm{NaCl}$ (T1); (3) $100 \mathrm{mM}$ $\mathrm{NaCl}+0.1 \mathrm{mM}$ SNP (NO, T2); (4) $100 \mathrm{mM} \mathrm{NaCl}+0.1$ mM SA (SA, T3); (5) $100 \mathrm{mM} \mathrm{NaCl}+0.05 \mathrm{mM}$ $\mathrm{SNP}+0.05 \mathrm{mM}$ SA (1/2(NO+SA, T4); (6) $100 \mathrm{mM}$ $\mathrm{NaCl}+0.1 \mathrm{mM} \mathrm{SNP}+0.1 \mathrm{mM} \mathrm{SA}(\mathrm{NO}+\mathrm{SA}, \mathrm{T} 5)$. The plants were sampled at 15 days after the treatment. The nutrient solution $\mathrm{pH}$ was adjusted to 6.8. Each of the glassware included 5 seedlings and represented one replicate, and there were three replicates per treatment. The treatment solution was changed everyday to maintain constant $\mathrm{NaCl}$ concentration.

\subsection{Determination of NO levels}

NO levels were determined according to the method described by Chen et al., (2010). Fresh samples were cut into approximately 5-mm segments and immediately incubated with $100 \mathrm{U}$ CAT and $100 \mathrm{U}$ SOD for 5 min to remove endogenous ROS before addition of oxyhemoglobin $(5 \mathrm{mM})$. After $3 \mathrm{~min}$ of incubation, NO was quantified by spectrophotometric measurement of the conversion of oxyhemoglobin to methemoglobin.

\subsection{Determination of SPAD reading}

The portable chlorophyll meter (SPAD-502, Minolta Camera Co., Japan) can estimate total chlorophyll amounts in the leaves of a variety of species with a high degree of accuracy, which is a non-destructive method. Measurements were taken at 4 locations on each leaf; two on each side of the midrib on all fully expanded leaves and then averaged (Khan et al., 2003). 


\subsection{Determination of ion concentration}

For determination of ion contents, $100 \mathrm{mg}$ of ground dry material of the leaf, stem and roots were digested by adding $4 \mathrm{~mL} \mathrm{HClO}_{4}$ at $200{ }^{\circ} \mathrm{C}$ until a colorless liquid was formed. After digestion, each sample was brought up to a $25 \mathrm{~mL}$ final volume with distilleddeionized water. The $\mathrm{Na}^{+}$and $\mathrm{K}^{+}$contents were determined with a flame photometer. The $\mathrm{Ca}^{2+}$ and $\mathrm{Mg}^{2+}$ contents were measured by flame atomic absorbance spectrometry (SHIMADZU AA-6300, Kyoto, Japan). The $\mathrm{Cl}^{-}$content was measured in accordance with Tsukada (2005).

\subsection{Determination of electrolyte leakage and lipid peroxidation}

Electrolyte leakage was used to assess the cell membrane permeability as described by Tariq et al., (2011). The leaves were rinsed three times with distilled water. Plant material (5-mm leaf discs) was transferred to each test vial containing $10 \mathrm{~mL}$ of double-distilled water. The vials were sealed and then placed on a rotary shaker for $24 \mathrm{~h}$. The electric conductivity $\left(\mathrm{EC}_{1}\right)$ of the content of the vial was determined, using an electrical conductivity meter (Metzer Optical Instruments, India). The vials were again sealed and autoclaved at $120{ }^{\circ} \mathrm{C}$ for $20 \mathrm{~min}$. The contents of the vials were cooled at room temperature, followed by recording the electric conductivity $\left(\mathrm{EC}_{2}\right)$ again. Membrane damage was calculated using the equation: $\mathrm{MD}(\%)=$ $\left(\mathrm{EC}_{1} / \mathrm{EC}_{2}\right) \times 100$.

Malondialdehyde (MDA) content uses the thiobarbituric acid reaction method (Heath \& Packer, 1968). Fresh samples $(0.2 \mathrm{~g})$ were ground in $3 \mathrm{~mL}$ of trichloroacetic acid $(0.1 \%, \mathrm{w} / \mathrm{v})$. The homogenate was centrifuged at $10,000 \times \mathrm{g}$ for $10 \mathrm{~min}$ and $1 \mathrm{ml}$ of the supernatant fraction was mixed with $4 \mathrm{~mL}$ of $0.5 \%$ thiobarbituric acid (TBA) in $20 \%$ TCA. The mixture was heated at $95{ }^{\circ} \mathrm{C}$ for $30 \mathrm{~min}$, chilled on ice, and then centrifuged at $10,000 \times \mathrm{g}$ for $5 \mathrm{~min}$. The absorbance of the supernatant was measured at $532 \mathrm{~nm}$. The value for non-specific absorption at $600 \mathrm{~nm}$ was subtracted. The amount of MDA was calculated using the extinction coefficient of $155 \mathrm{mM}^{-1} \mathrm{~cm}^{-1}$ and expressed as nmol g-1 $\mathrm{FW}$.

\subsection{Determination of endogenous ROS production}

The second fully expanded leaves of the plants were sampled for enzymatic analysis. Samples were homogenized in $0.05 \mathrm{M}$ phosphate buffer $(\mathrm{pH} 7.8)$ by grinding with a mortar and pestle under ice-cold condition. The homogenate was filtered through four layers of muslin cloth and centrifuged at $12,000 \times \mathrm{g}$ for $10 \mathrm{~min}$ at $4{ }^{\circ} \mathrm{C}$, and the supernatants were used for measurements of $\mathrm{O}_{2}$.' generation rate according to Sui et al. (2007). Fresh samples (1 g) were homogenized in $2 \mathrm{ml}$ ice-cold acetone. Titanium reagent $\left(2 \% \mathrm{TiCl}_{2}\right.$ in conc. $\mathrm{HCl}$ ) was added to one milliliter of extract supernatant to give a Ti (IV) concentration of $2 \%$. The Ti- $\mathrm{H}_{2} \mathrm{O}_{2}$ complex, together with unreacted Ti, was then precipitated by adding $0.2 \mathrm{ml} 17 \mathrm{M}$ ammonia solution for each $1 \mathrm{ml}$ of extract. The precipitate was washed five times with ice acetone by resuspension, drained, and dissolved in $1 \mathrm{M} \mathrm{H}_{2} \mathrm{SO}_{4}(3 \mathrm{ml})$. The absorbance of the solution was measured at $410 \mathrm{~nm}$ against blanks prepared similarly, however without plant tissue (Sui et al., 2007).

\subsection{Determination of proline content}

Proline was determined as described by Simaei et al., (2011). Fresh leaf tissues $(0.5 \mathrm{~g})$ from each treatment were homogenized in $10 \mathrm{~mL}$ of $3 \% \mathrm{w} / \mathrm{v}$ sulphosalicylic acid and the homogenate was filtrated. The resulting solution was treated with $2.5 \%$ ninhidrine solution and glacial acetic acid. In test tubes, the reac- 
tion mixtures were kept in a water bath at $100{ }^{\circ} \mathrm{C}$ for $60 \mathrm{~min}$ to develop the colors. Soon after removal from the water bath, the test tubes were cooled in ice bath and toluene was added to separate chromophores. Optical density was read at $520 \mathrm{~nm}$ using UV-VIS spectrophotometer (Shimadzu UV-2210).

\subsection{Determination of soluble sugar content}

Plants from each treatment/control were washed thoroughly with distilled water, cut into small pieces, weighed, placed separately in glass vials containing $10 \mathrm{~mL}$ of $80 \%(\mathrm{v} / \mathrm{v})$ ethanol, and heated at $60{ }^{\circ} \mathrm{C}$ for $30 \mathrm{~min}$. The extract was then filtered and diluted with $80 \%$ (v/v) ethanol up to $20 \mathrm{ml}$. The concentrations of soluble sugar were determined in this extract as described by Giannakoula et al. (2008).

\subsection{Enzyme extraction and enzyme assays}

For determination antioxidant enzymes, $0.5 \mathrm{~g}$ powder of freeze-dried leaves were homogenized with $50 \mathrm{mM}$ $\mathrm{Na}_{2} \mathrm{HPO}_{4}-\mathrm{NaH}_{2} \mathrm{PO}_{4}$ buffer ( $\mathrm{pH}$ 7.8) containing 0.2 $\mathrm{mM}$ EDTA and $2 \%$ insoluble polyvinylpyrrolidone in a chilled pestle and mortar. The slurry was centrifuged at $12,000 \times \mathrm{g}$ for $20 \mathrm{~min}$ and the supernatant was used for enzyme activities assay. The experiment was carried out at $4{ }^{\circ} \mathrm{C}$.

Total SOD activity was assayed by the photochemical method (Rao and Sresty 2000). The $3 \mathrm{~mL}$ reaction mixture contained $50 \mathrm{mM}$ phosphate buffer $(\mathrm{pH}$ 7.8), $13 \mathrm{mM}$ methionine, $75 \mu \mathrm{M}$ nitroblue tetrazolium, $2 \mathrm{mM}$ riboflavin, $10 \mathrm{mM}$ EDTA and $0.1 \mathrm{~mL}$ enzyme extract. One unit of the enzyme activity was defined as the amount of enzyme required to result in a $50 \%$ inhibition of the rate of nitro blue tetrazolium (NBT) reduction measured at $560 \mathrm{~nm}$. SOD activity was expressed as $\mathrm{U} \mathrm{g}^{-1} \mathrm{FW} \mathrm{min}^{-1}$. Guaiacol peroxidase (POD) activity was estimated after Nickel and Cunningham (1969) method. Activity was measured by the increase in absorbance at $470 \mathrm{~nm}$ due to guaiacol oxidation. The activity was expressed as $\mathrm{U}$ $\mathrm{g}^{-1} \mathrm{FW} \mathrm{min}^{-1}$. CAT activity was determined by following the consumption of $\mathrm{H}_{2} \mathrm{O}_{2}$ at $240 \mathrm{~nm}$ according to the method of Cakmak and Marschner (1992). CAT activity was expressed as $\mathrm{nmol} \mathrm{H}_{2} \mathrm{O}_{2} \mathrm{mg}^{-1} \mathrm{FW} \mathrm{min}{ }^{-1}$. 2.11. Statistical analysis

Each pot was treated as one replicate, and all the treatments were repeated three times. Excel 2003 software to process data and draw the table, the DPS software (DPS 7.05) for statistical analysis, and the least significant difference (LSD) was calculated to compare the differences between means in each treatment.

\section{Results}

\subsection{NO Production}

NO concentration in the leaves and roots increased dramatically after 5 days of $\mathrm{NaCl}$ treatment relative to the control (Figure 1). T1 increased leaves NO content by $37.86 \%$ compared to CK. T2 and T4 also increased leaves NO content by 98.92 and $109.49 \%$, respectively. Root NO concentration was similar to that of leaves of $\mathrm{NaCl}$ exposure. The $\mathrm{NO}$ content was significantly increased in roots under $\mathrm{NaCl}$ stress, but this increase was also effectively enhanced by application of exogenous SNP or/and SA, especially T4 treatment. To prove that the SNP-released NO, rather than other substances associated with SNP decomposition (such as cyanide and $\mathrm{Fe}$ ), was responsible for the SNP-induced alleviation effect on $\mathrm{NaCl}$ toxicity, $\mathrm{NaCl}$-treated cotton seedlings were treated with $100 \mu \mathrm{M} \mathrm{K}_{4} \mathrm{Fe}(\mathrm{CN})_{6}$ and $100 \mu \mathrm{M} \mathrm{SNP}+100 \mu \mathrm{M}$ cPTIO separately. And the plant fresh weight and dry weight were measured. The results indicated that treatment with neither $100 \mu \mathrm{M}$ SNP $+100 \mu \mathrm{M}$ 
cPTIO nor $100 \mu \mathrm{M} \mathrm{K}_{4} \mathrm{Fe}(\mathrm{CN})_{6}$ had an ameliorating effect on $\mathrm{NaCl}$-induced inhibition of cotton seedlings growth (Figure 2). This evidence proves the hypothesis that SNP-release NO, rather than other substances of SNP decomposition, accounts for the alleviation effect on $\mathrm{NaCl}$ toxicity.

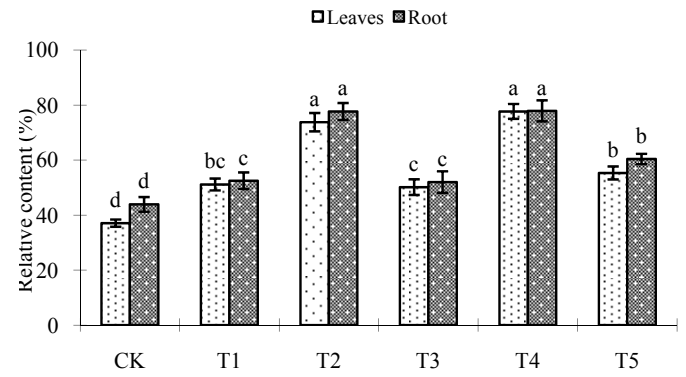

Figure 1. NO content in leaves and roots of cotton seedlings exposed to $\mathrm{NaCl}$ and as affected by SNP and SA. Values are the mean of three replicates.

Note: Values are the mean of three replicates. The values followed by the different letter show statistically significant differences at $P<0.05$. CK-control, T1-100 mM NaCl, T2-0.1 mM SNP, T3-0.1 mM SA, T4-0.05 mM SNP + 0.05 mM SA, T5-0.1 mM SNP + 0.1 mM SA.

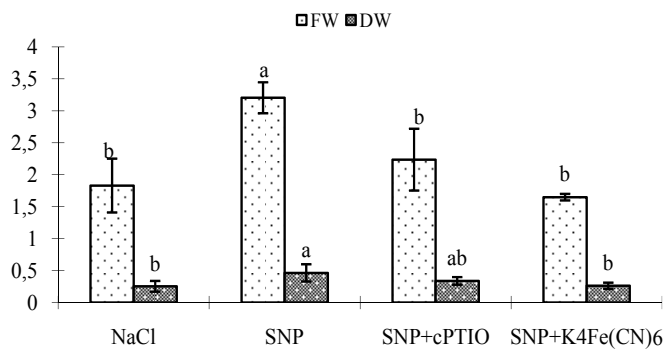

Figure 2. Effects of SNP, cPTIO and $\mathrm{K}_{4} \mathrm{Fe}(\mathrm{CN})_{6}$ on FW and DW in cotton seedlings subjected to $\mathrm{NaCl}$ stress. FW, fresh weight $\left(\right.$ g plant $\left.^{-1}\right)$; DW, dry weight $\left(\right.$ g plant $\left.^{-1}\right)$.
Note: Values are the mean of three replicates. The values followed by the different letter show statistically significant differences at $\mathrm{P}<0.05$. CK-control, T1-100 mM NaCl, T2-0.1 mM SNP, T3-0.1 mM SA, T4-0.05 mM SNP + 0.05 mM SA, T5-0.1 mM SNP + 0.1 mM SA.

\subsection{SPAD reading}

As shown in Figure 3A, the trend of SPAD reading change was determined during ten days. The SPAD reading was significantly decreased in T1 after 6 days, SNP or/and SA treatments can alleviate the symptoms. T1 treatment sharply decreased the SPAD reading by $32.9 \%$ with CK on the tenth day. T2 elevated the decreased the reading by $21.34 \%$ compared with T1 treatment, whereas T4 substantially enhanced concentration of chlorophyll on the tenth day, which was enhanced $36.67 \%$ compared with $\mathrm{T} 1$ treatment.

\section{3. $\mathrm{Na}, \mathrm{K}, \mathrm{Ca}, \mathrm{Mg}$, and $\mathrm{Cl}$ concentrations}

As shown in Table 1, in NaCl-treated plants, $\mathrm{Na}$ accumulated more in shoots than in roots. In the presence of SNP or/and SA, Na content decreased in roots and shoots, as compared to $\mathrm{T} 1$ treatment. $\mathrm{Cl}$ concentration was similar to that of $\mathrm{Na}$ in $\mathrm{NaCl}$ exposure. However, in contrast to $\mathrm{Na}$ accumulation, salinity significantly decreased $\mathrm{K}, \mathrm{Ca}$ and $\mathrm{Mg}$ content of cotton plants. Conversely, there was a slight rise in salt-stressed plants supplemented with SNP or/and SA than $\mathrm{NaCl}$ treated only (Table 1).

\subsection{Membrane damages and electrolyte leakage}

For the control plants, the level of MDA was low, but under T1 treatment, cotton seedlings showed higher concentrations of MDA. Both SNP and SA used in this study caused a decrease in the MDA contents (Table 2). Simultaneously, T4 (the combination of SNP and $\mathrm{SA}$ ) is remaining comparable to $\mathrm{CK}$. 

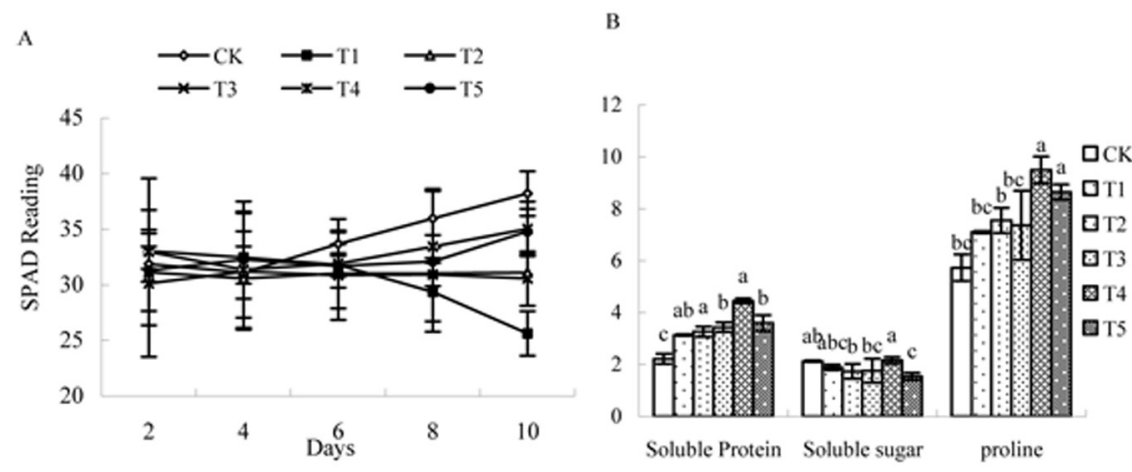

Figure 3. Effects of SNP and SA on SPAD reading (A) in cotton seedlings subjected to $\mathrm{NaCl}$ stress in ten days; Effects of SNP and SA for $\mathrm{NaCl}$ on proline, soluble protein and soluble sugar contents (B) in cotton seedlings subjected to $\mathrm{NaCl}$ stress. proline $\left(\mu \mathrm{mol} \mathrm{g}^{-1}, \mathrm{FW}\right)$; soluble protein $\left(\mathrm{mg} \mathrm{g}^{-1}, \mathrm{FW}\right)$; soluble sugar $\left(\mathrm{mg} \mathrm{g}^{-1}, \mathrm{FW}\right)$. Values are the mean of three replicates.

Note: Values are the mean of three replicates. The values followed by the different letter show statistically significant differences at $P<0.05$. CK-control, T1-100 mM NaCl, T2-0.1 mM SNP, T3-0.1 mM SA, T4-0.05 mM SNP + 0.05 mM SA, T5-0.1 $\mathrm{mM}$ SNP + $0.1 \mathrm{mM}$ SA.

$\mathrm{NaCl}$ treated plants exhibited a significant increase in electrolyte leakage. Application of SNP or/and SA decreased the level of electrolyte leakage in salt stressed plants (Table 2). T1 resulted in a $44.92 \%$ increase in electrolyte leakage as compared with CK whereas the electrolyte leakage was decreased by $24.87 \%$ and $13.85 \%$ in T4 and T5 treated plants as compared with $\mathrm{T} 1$.

\subsection{Endogenous ROS production and osmotic regula- tors accumulation}

The results show that excess $\mathrm{NaCl}$ led to an enhancement in $\mathrm{H}_{2} \mathrm{O}_{2}$ content in leaves, up to 0.95 times ( $p<$ $0.05)$ higher than those of CK plants, indicating an evident oxidative stress occurred in the $\mathrm{NaCl}$-stressed cotton leaves (Table 2). Application of SA or SNP, especially T4 treatment, significantly reduced $\mathrm{H}_{2} \mathrm{O}_{2}$ accumulation in NaCl-stressed plants. Similar to the moderating effect of $\mathrm{H}_{2} \mathrm{O}_{2}$, the SNP or SA could significantly decrease the $\mathrm{O}_{2}^{--}$generation rate that induced by salt.

Soluble protein in cotton leaves increased with 100 $\mathrm{mM} \mathrm{NaCl}$ levels (Figure 3B). And it increased in SNP or SA addition more sharply. T4 caused the most accumulation which was especially significant of CK. In addition, total proline showed a similar trend. T1 increased the content of soluble sugar measured in the leaves of salt-treated cotton plants. When compared to CK, salt stress increased soluble sugar of cotton plants by 2.15 -fold. When SNP or SA was applied to the plants, soluble sugar in the leaves showed a little decreased. Moreover, T4 almost nullified the effect of stress caused by $\mathrm{NaCl}$ and improved the soluble sugar significantly. 
Table 1. Effects of SNP and SA on $\mathrm{Na}(\%), \mathrm{K}(\%), \mathrm{Ca}\left(\mathrm{g} \mathrm{kg}^{-1}\right), \mathrm{Mg}\left(\mathrm{g} \mathrm{kg}^{-1}\right)$, and $\mathrm{Cl}$ contents $\left(\mathrm{mg} \mathrm{g}^{-1}\right)$ in cotton seedlings subjected to $\mathrm{NaCl}$ stress.

\begin{tabular}{cccccccc}
\hline Element/Type & \multicolumn{5}{c}{ Treatments } \\
\cline { 3 - 8 } of plant tissue & CK & T1 & T2 & T3 & T4 & T5 \\
\cline { 2 - 7 } $\mathrm{Na}$ & Leaves & $0.13 \pm 0.02 \mathrm{c}$ & $1.43 \pm 0.12 \mathrm{a}$ & $1.05 \pm 0.04 \mathrm{~b}$ & $1.34 \pm 0.04 \mathrm{~b}$ & $1.08 \pm 0.06 \mathrm{~b}$ & $1.38 \pm 0.11 \mathrm{a}$ \\
$\mathrm{N}$ & Stem & $0.43 \pm 0.02 \mathrm{c}$ & $2.79 \pm 0.47 \mathrm{a}$ & $2.62 \pm 0.23 \mathrm{a}$ & $2.69 \pm 0.24 \mathrm{a}$ & $2.18 \pm 0.08 \mathrm{~b}$ & $2.54 \pm 0.09 \mathrm{ab}$ \\
& Root & $0.43 \pm 0.03 \mathrm{c}$ & $2.63 \pm 0.29 \mathrm{a}$ & $1.61 \pm 0.02 \mathrm{~b}$ & $2.32 \pm 0.07 \mathrm{ab}$ & $1.88 \pm 0.12 \mathrm{~b}$ & $1.94 \pm 0.06 \mathrm{ab}$ \\
& Leaves & $2.27 \pm 0.35 \mathrm{a}$ & $1.83 \pm 0.83 \mathrm{~b}$ & $1.99 \pm 0.36 \mathrm{ab}$ & $2.25 \pm 0.27 \mathrm{ab}$ & $2.22 \pm 0.06 \mathrm{ab}$ & $2.14 \pm 0.11 \mathrm{ab}$ \\
$\mathrm{K} \mathrm{K}$ & Stem & $3.71 \pm 0.36 \mathrm{a}$ & $1.81 \pm 0.26 \mathrm{c}$ & $1.95 \pm 0.21 \mathrm{c}$ & $1.92 \pm 0.10 \mathrm{c}$ & $2.23 \pm 0.21 \mathrm{bc}$ & $2.44 \pm 0.36 \mathrm{~b}$ \\
& Root & $4.27 \pm 0.09 \mathrm{a}$ & $2.64 \pm 0.17 \mathrm{c}$ & $3.75 \pm 0.08 \mathrm{~b}$ & $3.03 \pm 0.11 \mathrm{c}$ & $4.08 \pm 0.51 \mathrm{ab}$ & $4.11 \pm 0.22 \mathrm{ab}$ \\
& Leaves & $150.22 \pm 11.22 \mathrm{ab}$ & $124.43 \pm 9.93 \mathrm{c}$ & $128.43 \pm 17.92 \mathrm{c}$ & $138.01 \pm 15.87 \mathrm{bc}$ & $156.13 \pm 22.07 \mathrm{a}$ & $150.12 \pm 26.14 \mathrm{ab}$ \\
$\mathrm{Ca}$ & Stem & $102.45 \pm 23.46 \mathrm{a}$ & $86.60 \pm 12.45 \mathrm{~b}$ & $90.02 \pm 3.39 \mathrm{~b}$ & $94.57 \pm 14.21 \mathrm{ab}$ & $100.62 \pm 23.32 \mathrm{a}$ & $95.92 \pm 10.97 \mathrm{ab}$ \\
& Root & $84.46 \pm 14.97 \mathrm{a}$ & $45.09 \pm 15.42 \mathrm{~b}$ & $56.38 \pm 5.65 \mathrm{~b}$ & $51.18 \pm 3.33 \mathrm{~b}$ & $75.39 \pm 13.64 \mathrm{a}$ & $74.56 \pm 8.90 \mathrm{a}$ \\
& Leaves & $2.45 \pm 0.22 \mathrm{~b}$ & $1.52 \pm 0.12 \mathrm{~d}$ & $2.10 \pm 0.19 \mathrm{c}$ & $2.21 \pm 0.08 \mathrm{bc}$ & $2.84 \pm 0.09 \mathrm{a}$ & $2.82 \pm 0.17 \mathrm{a}$ \\
$\mathrm{Mg}$ & Stem & $2.80 \pm 0.42 \mathrm{a}$ & $1.65 \pm 0.03 \mathrm{c}$ & $2.12 \pm 0.04 \mathrm{~b}$ & $1.70 \pm 0.03 \mathrm{c}$ & $1.68 \pm 0.08 \mathrm{c}$ & $1.66 \pm 0.03 \mathrm{c}$ \\
& Root & $3.83 \pm 0.12 \mathrm{~b}$ & $2.98 \pm 0.18 \mathrm{f}$ & $3.67 \pm 0.28 \mathrm{c}$ & $3.03 \pm 0.41 \mathrm{e}$ & $3.96 \pm 0.64 \mathrm{a}$ & $3.62 \pm 0.19 \mathrm{~d}$ \\
& Leaves & $0.12 \pm 0.02 \mathrm{e}$ & $1.63 \pm 0.10 \mathrm{a}$ & $0.93 \pm 0.06 \mathrm{c}$ & $1.28 \pm 0.05 \mathrm{~b}$ & $0.74 \pm 0.04 \mathrm{~d}$ & $0.87 \pm 0.06 \mathrm{c}$ \\
$\mathrm{Cl}$ & Stem & $0.41 \pm 0.13 \mathrm{e}$ & $2.47 \pm 0.07 \mathrm{a}$ & $1.92 \pm 0.03 \mathrm{~b}$ & $1.77 \pm 0.07 \mathrm{bc}$ & $1.35 \pm 0.05 \mathrm{~d}$ & $1.67 \pm 0.18 \mathrm{c}$ \\
& Root & $0.35 \pm 0.04 \mathrm{c}$ & $1.57 \pm 0.22 \mathrm{a}$ & $1.61 \pm 0.42 \mathrm{a}$ & $1.55 \pm 0.05 \mathrm{a}$ & $1.25 \pm 0.14 \mathrm{~b}$ & $1.63 \pm 0.22 \mathrm{a}$ \\
\hline
\end{tabular}

Notes: Values are the means $\pm \mathrm{SD}$ of three replicates. The values followed by the different letter show statistically significant differences at $P<0.05$. CK-control, T1-100 mM NaCl, T2-0.1 mM SNP, T3-0.1 mM SA, T4-0.05 mM SNP + 0.05 mM SA, T5-0.1 mM SNP + $0.1 \mathrm{mM} \mathrm{SA}$.

Table 2. Effects of SNP and SA on MDA content, electrolyte leakage and antioxidant enzymes in cotton seedlings subjected to $\mathrm{NaCl}$ stress. MDA content ( $\left.\mu \mathrm{mol} \mathrm{g}{ }^{-1} \mathrm{FW}\right)$; Electrolyte leakage (\%); $\mathrm{O}_{2}$. 'generation rat $\left(\mu \mathrm{mol} \mathrm{g}^{-1} \mathrm{~h}^{-1}\right)$; $\mathrm{H}_{2} \mathrm{O}_{2}\left(\mu \mathrm{mol} \mathrm{g} \mathrm{g}^{-1} \mathrm{FW}\right)$; CAT, catalase, $\left(\mu \mathrm{mol} \mathrm{H}_{2} \mathrm{O}_{2} \mathrm{mg}^{-1} \mathrm{~min}^{-1} \mathrm{FW}\right)$; POD, peroxidase, $\left(\mathrm{U} \mathrm{mg}^{-1} \mathrm{~min}^{-1} \mathrm{FW}\right)$; SOD, superoxide dismutase (units $\mathrm{g}^{-1} \mathrm{FW}$ ).

\begin{tabular}{ccccccc}
\hline & \multicolumn{5}{c}{ Treatments } \\
\cline { 2 - 7 } & $\mathrm{CK}$ & $\mathrm{T} 1$ & $\mathrm{~T} 2$ & $\mathrm{~T} 3$ & $\mathrm{~T} 4$ & $\mathrm{~T} 5$ \\
\hline MDA & $10.40 \pm 0.14 \mathrm{e}$ & $28.97 \pm 1.63 \mathrm{a}$ & $19.59 \pm 0.13 \mathrm{~b}$ & $18.01 \pm 0.89 \mathrm{c}$ & $11.98 \pm 0.68 \mathrm{~d}$ & $17.64 \pm 0.55 \mathrm{c}$ \\
Electrolyte leakage & $40.62 \pm 1.33 \mathrm{~d}$ & $58.86 \pm 6.74 \mathrm{a}$ & $45.78 \pm 2.38 \mathrm{c}$ & $53.44 \pm 5.36 \mathrm{~b}$ & $44.22 \pm 2.44 \mathrm{c}$ & $50.71 \pm 2.36 \mathrm{~b}$ \\
$\mathrm{O}_{2}{ }^{-}$generation rate & $17.17 \pm 1.80 \mathrm{~b}$ & $26.40 \pm 2.52 \mathrm{a}$ & $18.13 \pm 1.44 \mathrm{~b}$ & $19.06 \pm 2.62 \mathrm{~b}$ & $16.82 \pm 0.45 \mathrm{~b}$ & $18.37 \pm 1.12 \mathrm{~b}$ \\
$\mathrm{H}_{2} \mathrm{O}_{2}$ & $1.38 \pm 0.76 \mathrm{c}$ & $4.59 \pm 0.35 \mathrm{a}$ & $2.30 \pm 0.68 \mathrm{~b}$ & $2.36 \pm 0.28 \mathrm{~b}$ & $1.71 \pm 0.45 \mathrm{bc}$ & $1.91 \pm 0.37 \mathrm{bc}$ \\
$\mathrm{CAT}$ & $3.90 \pm 0.26 \mathrm{a}$ & $2.38 \pm 0.11 \mathrm{~b}$ & $2.64 \pm 0.10 \mathrm{~b}$ & $3.70 \pm 0.59 \mathrm{a}$ & $3.72 \pm 0.41 \mathrm{a}$ & $4.00 \pm 0.06 \mathrm{a}$ \\
POD & $590.11 \pm 86.01 \mathrm{a}$ & $496.16 \pm 33.61 \mathrm{~b}$ & $541.97 \pm 45.65 \mathrm{ab}$ & $521.51 \pm 34.25 \mathrm{ab}$ & $582.66 \pm 32.70 \mathrm{a}$ & $547.30 \pm 26.86 \mathrm{ab}$ \\
$\mathrm{SOD}$ & $92.51 \pm 3.46 \mathrm{a}$ & $72.31 \pm 0.80 \mathrm{~b}$ & $81.72 \pm 5.69 \mathrm{ab}$ & $79.38 \pm 18.65 \mathrm{ab}$ & $85.09 \pm 2.91 \mathrm{ab}$ & $88.02 \pm 4.91 \mathrm{a}$ \\
\hline
\end{tabular}

Notes: Values are the mean of three replicates. The values followed by the different letter show statistically significant differences at $P<0.05$. CK-control, T1-100 mM NaCl, T2-0.1 mM SNP, T3-0.1 mM SA, T4-0.05 mM SNP + 0.05 mM SA, T5-0.1 mM SNP + 0.1 mM SA 


\subsection{Antioxidant enzymes}

Since $\mathrm{NaCl}$ treatment caused oxidative stress in cotton plants, we examined the behavior of the antioxidant enzymes next. SOD activity was inhibited by $17.85 \%$ in leaves of cotton plants treated with $\mathrm{T} 1$ as compared with CK. When SNP and SA were added to nutrient solution containing $\mathrm{NaCl}$, SOD activity increased by $17.67 \%$ and $27.94 \%$ respectively in leaves. The POD activity in leaves of T1-treated plants decreased by $15.92 \%$ as compared with CK. When NaCl-stressed plants were treated with SA or SNP, POD activity significantly increased in leaves. Whereas treated with $\mathrm{T} 4$, in NaCl-treated plants, the POD activity was increased by $17.43 \%$ compared with $\mathrm{NaCl}$-treated alone. The CAT activity in leaves of T1-treated plants was decreased by $38.94 \%$ as compared with CK. When SA and SNP were added to nutrient solution containing $\mathrm{NaCl}$, the $\mathrm{CAT}$ activity of leaves and roots increased. In NaCl-treated plants, SNP or SA, especially T4 improved the enzyme activity in comparison to $\mathrm{NaCl}$-treated plants.

\section{Discussion}

Nitric oxide (NO) as a ubiquitous signal molecule participates in major physiological processes in plant growth and development, and in response to biotic and abiotic stresses (Wilson, 2008). A notable increase of NO content was detected in the cotton seedlings exposed to $100 \mathrm{mM} \mathrm{NaCl}$, whereas there was more increase in that of the SNP treatment under $\mathrm{NaCl}$-stress (Figure 1). NaCl-induced inhibition of fresh and dry weight was significantly reversed when cotton seedlings were treated with SNP (Figure 2), compared with the treatment of the $\mathrm{CPTIO}$ and $\mathrm{K}_{4} \mathrm{Fe}(\mathrm{CN})_{6}$. These evidences proved the hypothesis that SNP-released NO, rather than other substances of SNP decomposition, accounts for the alleviation effect on $\mathrm{NaCl}$ toxicity.
In this work, we analyzed the possible role of exogenous SNP and SA in the modulation of the antioxidant defense system against $\mathrm{NaCl}$ stress in cotton seedlings. Evidences have been demonstrated that the interaction between $\mathrm{NO}$ andSA had synergistic effects in decreasing of the damages induced by all kinds of abiotic stress(Simaei et al., 2011; Gil'vanova et al., 2012). In the present study, we were able to increase the cotton antioxidant capacity and its components under salinity by applying NO and SA. Measurement of SPAD reading under salinity conditions explained that $\mathrm{NaCl}$ has the negative effects of chlorophyll contents. Treated with NO or / and SA, especially the combination of SNP and SA, decreased these damages induced by salt (Figure 3A). The decrease in SPAD reading in salt-affected plants might be attributed to the possible oxidation of chlorophyll and other chloroplast pigments coupled with instability of the pigment protein complex under salt stress (Tariq et al., 2003). Exogenous SNP and SA lead to the promotion of protective reactions to the photosynthetic pigments and induce a pre-adaptive response to salt stress ( $\mathrm{Si}$ maei et al., 2011), which confirms our results.

In addition, the correlations between and among various non-enzyme indices (e.g., ions content, leaf electrolyte leakage, MDA content, $\mathrm{H}_{2} \mathrm{O}_{2}$ content, $\mathrm{O}_{2}-$ generation rate, proline contents, and soluble sugar) and enzyme indices (e.g., CAT, POD, and SOD) in cotton seedlings subjected to salt stress were analyzed. Results showed that significant cor-relations existed between these nonenzyme indices and enzyme parameters. The contents of $\mathrm{Na}$ and $\mathrm{Cl}$ increased in leaves, stems and roots of the cotton under $\mathrm{NaCl}$ treatment, while an opposite trend for $\mathrm{K}, \mathrm{Ca}$ and $\mathrm{Mg}$ content was obtained (Table 1). $\mathrm{Na}$ and $\mathrm{Cl}$, entering into the cytoplasm through the cell membrane, lead to their accumulation in the cytoplasm, decreasing the availability of some of the essential nutrients as well (Deinlein, 2014). On the other hand, the excess of $\mathrm{Na}$ in the nutrient media led to the 
accumulation of $\mathrm{H}_{2} \mathrm{O}_{2}$ in cotton leaves and SNP/SA led to eliminating the accumulation (Table 2). High concentration of $\mathrm{Na}$ caused membrane disorganization. As the second messenger, $\mathrm{Ca}$ in cytosolic was increased, might induce further physiological response including the expression of osmotic responsive genes for salt adaptation in plants. This facilitation could be attributed to the induction of antioxidant responses and elevated $\mathrm{Ca}$ uptake that protects the plants from the oxidative damage by SNP and SA (El-tayeb et al., 2005). In addition, alteration of mineral uptake from NO and SA applications may be one mechanism for the alleviation of salt stress.

Also, excessive accumulation of $\mathrm{Na}$ in the cytosol has an adverse effect on maintaining a stable electrical conductivity of solution. Electrolyte leakage indicates cell membrane injury when plants are subject to salinity stress. The leaves electrolyte leakage was significantly affected by the salt stress treatments, but not the NO/SA concentrations and their interactions (Table 2). Maintenance of the integrity of cellular membranes under salt stress is considered an integral part of the mechanism of salinity tolerance (Tariq et al., 2003). Studies suggested the SA facilitated maintenance of membrane functions through induction of antioxidant mechanisms and elevated ion uptake, thereby protecting the plants against the oxidative damage (El-tayeb et al., 2005). While, NO effectively reduce the level of ROS generated during stress, and thus, limit oxidative damage in plant cells (Arasimowicz et al., 2007). According to the cited authors, the application of NO and SA, which facilitated maintenance of membrane functions under salt stress, could be an indicator of the build-up of a protective mechanism to reduce cytoplasm fluid leakage induced by salt stress.

Application of $\mathrm{NO}$ and/or SA reduced $\mathrm{NaCl}$-induced increase in the content of MDA (Table 2). It was suggested that superoxide anion $\left(\mathrm{O}_{2}^{\circ}\right), \mathrm{H}_{2} \mathrm{O}_{2}$, radicals of hydroxyl $(\mathrm{OH} \bullet)$, lipid alcoxyl $(\mathrm{LO} \bullet)$, and lipid peroxyl
(LOO•), which are produced during salinity, can be the major factors responsible for lipid peroxidation. The level of MDA, product of lipid peroxidation, has been considered an indicator of oxidative damage (Li et al., 2008). Decreased lipid peroxidation against oxidative stress, may assist in overcoming severe stresses and providing a rapid recovery. $\mathrm{Li}$ (2008) also indicated that salt stress could cause damages to the integrity of the cellular membrane such as lipids that was sensitive to oxidative stress. SA was reported to inhibit production of hydroxyl radical and to decrease the content of MDA (Gunes et al., 2005). Proline is able to scavenge hydroxyl radical and stabilize the structure and function of macromolecules and structures, such as DNA, protein, and membranes (Misra et al., 2009). It can be clearly seen that $\mathrm{NaCl}$ induced proline accumulation (Figure 3B). It has been reported that SA, through the induction of ABA-mediated proline production, can decrease the deleterious effects of salt stress and water deficit in wheat seedlings (Sakhabutdinova et al., 2003). Because MDA and proline are often considered a compatible solute involved in osmotic adjustment under stress, reduction in the level of MDA and increase in the level of proline in $(\mathrm{NO}+\mathrm{SA})$-treated plants indicate the stress amelioration role of $\mathrm{NO}$ and SA that might be responsible for maintenance of plant growth under stress.

Salinity has been shown to reduce water uptake by roots because of lowered osmotic potentials of the substrate, and to cause changes in metabolic activities leading to the reduction in plant growth (Jaleel et al. 2007). The overall reduction in the growth of cotton seedlings might be ascribed to the ill effect of salt stress on the various physiological processes such as photosynthesis, ion homeostasis, accumulation of compatible solutes, and activities of antioxidant enzymes. The content of soluble protein is significantly increased in the leaves at the $\mathrm{NaCl}$-treated (Figure 3B). With respect to the salinized plants, soluble protein content increased 
significantly in leaves with T4 treatment than other treatments. SA treatment induced more accumulation of soluble sugar of the stressed plants (Khodary et al., 2009). Soluble sugar can be involved in, or related to, ROS-producing metabolic pathways. It might either directly detoxify ROS in chloroplasts and vacuoles or indirectly stimulate the classic antioxidative defense systems (Khodary et al., 2009). In this regard, it is assumed that, 1/2 (SNP+SA) may stimulate hydrolysis of proteins, providing a pool of compatible osmolyte, which is important in osmotic adjustment in the presence of sodium.

Furthermore, electron transport processes, such as photosynthesis and respiration, generate basal levels of $\mathrm{H}_{2} \mathrm{O}_{2}$, which is increased in response to stress ( $\mathrm{Si}-$ maei et al., 2011). Under salt stress, plants are overloaded with ROS, which inhibit several plant processes and cause damage to plants in different ways. Thus, to maintain metabolic functions under stress, scavenging of ROS is essential. ROS scavenging depends on detoxification mechanisms provided by antioxidant enzymes. The increase in the activities of CAT and SOD in $\mathrm{NaCl}$-treated plants has been documented by various workers investigating salinity stress in several plant species (Tariq et al., 2011). In this regard, CAT appears to play an essential protective role in scavenging ROS in coordination with SOD. SOD initiates detoxification of singlet oxygen by producing $\mathrm{H}_{2} \mathrm{O}_{2}$, which is eliminated by its conversion to $\mathrm{H}_{2} \mathrm{O}$ in subsequent reactions. It was suggested that $\mathrm{H}_{2} \mathrm{O}_{2}$ was key regulators of plant responses to a range of endogenous signals, which are involved in developmental processes, such as seed germination, and root development (Khan et al., 2003). SNP and SA-induced CAT and SOD activities increase indicate that they can play a critical role in modulating the cell redox balance, thereby protecting plants against oxidative damage. In our study, the CAT and SOD activities were higher in $\mathrm{T} 5(0.1 \mathrm{mM} \mathrm{NO}+0.1 \mathrm{mM}$ $\mathrm{SA})$ were higher than $\mathrm{T} 4(0.05 \mathrm{mM} \mathrm{SNP}+0.05 \mathrm{mM}$
SA), which maybe associated with promoting the absorption of $\mathrm{K}$, but the reason need further research. Contents of endogenous $\mathrm{H}_{2} \mathrm{O}_{2}$ and $\mathrm{O}_{2}{ }^{--}$were measured to determine the internal ROS status induced in cotton exposure to salinity treatments. Contents of $\mathrm{H}_{2} \mathrm{O}_{2}$ and $\mathrm{O}_{2}^{-}$- were higher in plants treated with $\mathrm{NaCl}$, indicating an increase in ROS level of the cells in salt-treated plants. Among the antioxidant enzymes, CAT and SOD are well known ROS scavengers. When the ROS contents exceed their threshold level under stress, they are scavenged by these enzymes. SNP and SA treatment increased CAT and SOD activities to scavenge the elevated level of ROS in this study.

\section{Conclusion}

In summary, SNP combined with SA $(0.05 \mathrm{mM}$ $\mathrm{SNP}+0.05 \mathrm{mM} \mathrm{SA}$ ) could play a better role to reduce oxidative stress unlike them alone, improve $\mathrm{Ca}^{2+} \mathrm{Mg}^{2+}$ and decrease $\mathrm{Na}^{+}$absorption, enhance the activity of antioxidant enzymes, trigger the accumulation of endogenous osmotic regulators for the facilitatation of the membrane transport and ROS detoxifying. The data also showed only the optimum concentration of SNP and SA could act directly on oxidative stress to promote salt-tolerance and plant growth.

\section{Acknowledgements}

The authors thank English lecturer Xiujuan Wang (College of Foreign Languages, Shandong Agricultural University) for their critical reading and revision of the manuscript. Special acknowledgements are given to the editors and reviewers. This work was financially supported by the Chinese National Basic Research Program (2015CB150404), indigenous innovation project of Shandong province (2014 ZZCX07401) and a Project of Shandong Agricultural University saline and alkaline land (75030). 


\section{References}

Arasimowicz, M., Floryszak-Wieczorek, J. 2007). Nitric oxide as a bioactive signalling molecule in plant stress responses. Plant Sci. 172, 876-887.

Chen, F., Wang, F., Sun, H., Cai, Y., Mao, W., Zhang, G., Vincze, E., Wu, F . 2010. Genotype-Dependent Effect of Exogenous Nitric Oxide on Cdinduced Changes in Antioxidative Metabolism, Ultrastructure, and Photosynthetic Performance in Barley Seedlings (Hordeum vulgare). J. Plant Growth Regul. 29, 394-408

Cakmak, I., Marschner, H. 1992. Magnesium deficiency and high light intensity enhance activities of superoxide dismutase, ascorbate peroxidase, and glutathione reductase in bean leaves. Plant Physiol. 98, 1222-1227.

Deinlein, U., Stephan, A.B., Horie, T., Luo, W., Xu, G., Schroeder, J.I. 2014. Plant salt-tolerance mechanisms. Trends Plant Sci. 19(6):371-379.

Dong, Y. , Jinc, S., Liu, S., Xu, L., Kong, J. 2014. Effects of exogenous nitric oxide on growth of cotton seedlings under $\mathrm{NaCl}$ stress. Journal of Soil Science and Plant Nutrition, 14(1), 1-13.

El-tayeb, M .2005. Response of barley grains to the interactive effect of salinity and salicylic acid. Plant Growth Regul. 45, 215-224.

Giannakoula, A., Moustakas, M., Mylona, P., Ioannis, P., Traianos, Y. 2008. Aluminium tolerance in maize is correlated with increased levels of mineral nutrients, carbohydrates and proline and decreased levels of lipid peroxidation and $\mathrm{Al}$ accumulation. J Plant Physiol. 165, 385-396.

Gunes, A., Inal, A., Alpaslan, M., Cicek, N., Esra, G., Figen, E., Tutku, G. 2005. Effects of exogenously applied salicylic acid on the induction of multiple stress tolerance and mineral nutrition in maize
(Zea mays L.). Archives of agronomy and soil science. 51, 687-695.

Gil'vanova, I.R., Enikeev, A.R.,Stepanov, S.,Rakhmankulova, Z.F. 2012. Involvement of salicylic acid and nitric oxide in protective reactions of wheat under the influence of heavy metals. Appl Biochem Micro. 48(1), 90-94.

Heath, R.L., Packer, L. 1968. Photoperoxidation in isolated chloroplasts. I: kinetics and stoichiometry of fatty acid peroxidation. Archives of Biochemistry and Biophysics. 125,189-198.

Jaleel, C.A., Gopi, R., Panneerselvam, R. 2007. Alterations in lipid peroxidation, electrolyte leakage, and proline metabolism in Catharanthus roseus under treatment with triadimefon, a systemic fungicide. Comptes Rendus Biologies. 330(12),905-912.

Khan, W., Prithiviraj, B., Smith, D.L.2003. Photosynthetic responses of corn and soybean to foliar application of salicylates. Journal of Plant Physiology $160,485-492$.

Khodary S. E.A .2009.Effect of salicylic acid on the growth, photosynthesis and carbohydrate metabolism in salt-stressed maize plants, International Journal of Agriculture and Biology 6, 5-8.

Lamattina, L., Garcia-Mata, C., Graziano, M., and Pagnussat, G.2003. Nitric oxide: the versatility of an extensive signal molecule. Annu. Rev. Plant Biol. 54,109-136.

Li, Q., Niu, H., Yin, J., Wang, M., Shao, H., Deng, D., Chen, X., Ren, J., Li, Y.. 2008. Protective role of exogenous nitric oxide against oxidative-stress induced by salt stress in barley (Hordeum vulgare). Colloid Surface B. 65,220-225.

Liu, S., Dong, Y., Xu, L.,Kong, J., Bai, X..2013.Roles of exogenous nitric oxide in regulating ionic equilibrium and moderating oxidative stress in cotton seedlings during salt stress. Journal of Soil Science and Plant Nutrition. 13 (4), 929-941. 
Lu, X., Wang, D., Yin, Z., Wang, J., Fan, W., Wang, S., Zhao, X., Zhang, T., Ye, W. 2014. Genomic DNA Methylation Polymorphism Analysis of Cotton Under $\mathrm{NaCl}$ and $\mathrm{Na}_{2} \mathrm{CO}_{3}$ Stress. Scientia Agricultura Sinica. 47(16), 3132-3142.

Manai, J., Kalai, T., Gouia, H., Corpas, F. J. 2014. Exogenous nitric oxide (NO) ameliorates salinityinduced oxidative stress in tomato (Solanum lycopersicum) plants. Journal of Soil Science and Plant Nutrition, 14 (2), 433-446.

Misra, N., Saxena, P.2009. Effect of salicylic acid on proline metabolism in lentil grown under salinity stress. Plant Science. 177,181-189.

Nickel, K..S, Cunningham, B.A. .1969.Improved peroxidase assay method using Leuco 2,3,6-trichloro indophenol and application to comparative measurements of peroxidase catalysis. Ann Clin Biochem. 27, 292-299.

Panda, P., Nath, S., Thorny, C.T., Sharma, G.D., Panda, S.K . 2011. Cadmium stress-induced oxidative stress and role of nitric oxide in rice (Oryza sativa L.). Acta Physiol Plant. 3,1737-1747.

Qadir, M., Noble, A.D., Schubert, S., Thomas, R.J., Arslan, A .2006. Sodicity-induced land degradation and its sustainable management: problems and prospectives. Land Degrad Dev. 17, 661-676.

Rao, K.V.M., Sresty, T.V.S .2000. Antioxidative parameters in the seedlings of pigeon pea (Cajanus cajan L. Millspaugh) in response to $\mathrm{Zn}$ and $\mathrm{Ni}$ stresses. Plant Sci. 157, 113-128.

Simaei, M., Khavarinejada, R.A., Saadatmanda, S., Bernardb, F., Fahimia, H .2011. Interactive Effects of Salicylic Acid and Nitric Oxide on Soybean Plants under $\mathrm{NaCl}$ Salinity. Russian Journal of Plant Physiology. 5, 783-790.

Sanjib, K.P., Hemanta, K.P .2007.Effect of salicylic acid potentiates cadmium-induced oxidative damage in Oryza sativa L. leaves. Acta Physiol Plant 29, 567-575.
Sakhabutdinova, A.R., Fatkhutdinova, D.R., Bezrukova, M.V., Shakirova, F.M..2003. Salicylic Acid Prevents the Damaging Action of Stress Factor in Wheat Plants. Bulg. J. Plant Physiol , 314-319.

Sui, N., Liu, X.Y., Wang, N., Fang,W., Meng, Q.W .2007.Response of xanthophylls cycle and chloroplastic antioxidant enzymes to chilling stress in tomato over-expressing glycerol-3-phosphate acyltransferase gene. Photosynthetica. 45, 447-454.

Silva, E.N., Ferreira-Silva, S.L., Fontenele, A.V., Ribeiro, R.V., Viégas, R.A., Silveira, J.A.G.2010. Photosynthetic changes and protective mechanisms against oxidative damage subjected to isolated and combined drought and heat stresses in Jatropha curcas plants. J Plant Physiol. 167:,157-1164.

Sheetal, C., Sunita, J., Veena, J.2012. Salinity induced oxidative stress and antioxidant system in salttolerant and salt-sensitive cultivars of rice (Oryza sativa L.). Journal of Plant Biochemistry and Biotechnology. doi: 10.1007/s13562-012-0107-4.

Tariq, A., Masroor, M., Khan, A., Jaime, A., Teixeira, D.S., Mohd, I., Naeem, M. 2011.Role of Salicylic Acid in Promoting Salt Stress Tolerance and Enhanced Artemisinin Production in Artemisia annua L. J Plant Growth Regul. 30, 425-435.

Tsukada H, Takeda A, Hasegawa H, Ueda S, Iyogi T, Radioanal J .2005.Nucl. Chem. 263: 773.

Wang ,X., Mohamed, I., Xia, Y., Chen, F.2014. Effects of water and potassium stresses on potassium utilization efficiency of two cotton genotype. Journal of Soil Science and Plant Nutrition. 14 (4), 833-844.

Wilson, I.D., Neill, S.J., Hancock, J.T. 2008. Nitric Oxide synthesis and signaling in plants. Plant Cell Environ. 31, 622-631.

Xiong, J., An, L.Y., Lu, H., Zhu, C. 2009. Exogenous nitric oxide enhances cadmium tolerance of rice by increasing pectin and hemicellulose contents in root cell wall. Planta. 230, 755-765. 